\title{
The Effects of Remote Pandemic Education on Crafts Pedagogy: Opportunities, Challenges, and Interaction
}

Anna Kounia ${ }^{* 1}$, KaIju Kangas ${ }^{2}$ And Sirpa KoKKO ${ }^{2}$

$\approx$ The Covid-19 pandemic caused many sudden social changes, including a shift to remote education in many countries. In Finland, remote education also concerns crafts as a standard school subject, combining aspects of art, design, textile, and technology in basic education. Accordingly, Finnish craft teachers faced the unprecedented situation of teaching remotely a subject, which often involves hands-on activities with tangible tools and materials. The present study explores how craft pedagogy has been adapted to remote education by looking at the opportunities and challenges it faces and the effects on classroom interaction. The data consist of the output of two webinars (i.e. 27 group assignments from 123 participants) organised in the autumn of 2020 and targeted at craft teachers and student craft teachers at various levels of the education system. The qualitative, data-driven content analysis reveals that remote teaching provides beneficial opportunities for involving students' everyday lives and families in craft education. However, challenges exist relating to the unequal distribution of materials, as well as technical and social resources at different levels of education and in various contexts. Our study also finds that remote teaching is more teacher-centred and task-oriented than classroom interaction. Online teaching facilities allow teachers to provide students with more individual feedback but make maintaining students' peer interaction difficult. Although remote craft education was considered very challenging at first, teachers have managed to create useful pedagogical practices to be utilised in and beyond the era of the Covid-19 pandemic.

Keywords: crafts, craft education, remote pedagogy, distance learning, pandemic pedagogy

$1{ }^{\star}$ Corresponding Author. Faculty of Educational Sciences, University of Helsinki, Finland; anna.kouhia@helsinki.fi.

2 Faculty of Educational Sciences, University of Helsinki, Finland. 


\section{Učinki pandemičnega izobraževanja na daljavo na obrtno pedagogiko: priložnosti, izzivi in interakcija}

Anna Kouhia, Kaiju Kangas in Sirpa KoKko

$\propto$ Pandemija covida-19 je v veliko državah povzročila številne nenadne družbene spremembe, med drugim tudi prehod na izobraževanje na daljavo. Na Finskem se izobraževanje na daljavo nanaša tudi na obrt kot na navaden šolski predmet, ki v osnovnem izobraževanju združuje vidike umetnosti, oblikovanja, tekstila in tehnologije. Skladno s tem so se finski učitelji obrti spoprijeli s situacijo poučevanja na daljavo brez primerov, ki pogosto vključujejo praktične dejavnosti z otipljivimi orodji in materiali. Ta raziskava preučuje, kako se je obrtna pedagogika prilagodila izobraževanju na daljavo, pri čemer obravnava priložnosti in izzive, $s$ katerimi se spoprijema, in učinke na interakcijo v razredu. Podatki so sestavljeni iz rezultatov dveh spletnih seminarjev (tj. 27 skupinskih na$\log 123$ udeležencev), ki sta bila organizirana jeseni 2020 ter namenjena učiteljem in študentom obrti na različnih ravneh izobraževalnega sistema. Kvalitativna vsebinska analiza, ki temelji na podatkih, razkriva, da poučevanje na daljavo zagotavlja koristne priložnosti za vključevanje vsakdanjega življenja učencev in njihovih družin v obrtno izobraževanje. Ostajajo pa izzivi, povezani z neenakomerno porazdelitvijo gradiv ter tehničnih in socialnih virov na različnih ravneh izobraževanja in $\mathrm{v}$ različnih kontekstih. Naša raziskava tudi ugotavlja, da je poučevanje na daljavo bolj osredinjeno na učitelja in nalogo kot interakcija v razredu. Spletni učni pripomočki učiteljem omogočajo, da učencem zagotovijo več individualnih povratnih informacij, vendar otežujejo vzdrževanje medsebojne interakcije učencev. Čeprav se je zdelo poučevanje obrti na daljavo najprej zelo zahtevno, je učiteljem uspelo ustvariti koristne pedagoške prakse, ki jih je mogoče uporabiti v obdobju pandemije covida-19 in po njem.

Ključne besede: obrt, obrtno izobraževanje, pedagogika na daljavo, učenje na daljavo, pandemična pedagogika 


\section{Introduction}

Prior to the pandemic, online teaching and learning mostly offered alternative ways of studying. Previous studies have recognised that online education operated from a distance has been crucial in providing education to remote places with few students or in offering courses on specific topics not available for many learners otherwise (e.g. Øgaard, 2018). Indeed, online and remote education can be effectively delivered if it is well designed and carefully planned. In contrast to this, the Covid-19 pandemic threw educators into a situation that required them to change their pedagogy almost overnight (e.g. Iivari et al., 2020; Niemi \& Kousa, 2020). This sudden shift has been called 'emergency remote teaching and learning' (ERT) and 'pandemic education' (Hodges et al., 2020; Milman, 2020).

Pandemic remote education forced teachers to seek new pedagogical approaches to teaching crafts, and there is a need for research on their experiences and pedagogical solutions. In this article, we use 'remote' education to refer to the teaching and learning of crafts utilising virtual and digital means in a way that is not necessarily online all the time (Ilomäki \& Lakkala, 2020) or 'distant' in the sense of attempting to reach faraway places (Øgaard, 2018). Moreover, we use 'pandemic' to refer to the situation specifically caused by the Covid-19 crisis.

Only about a year after the outbreak of Covid-19, research has broadly explored the implications of pandemic pedagogy for art and design education, notably how art and craft teachers have strived to reach the requirements of the curriculum without face-to-face and material interaction (Coleman \& MacDonald, 2020; Freedman \& Escaño, 2020; Kini-Singh, 2020). Continuing this line of research, this study aims to provide an understanding of the challenges and opportunities of remote education from the perspective of craft pedagogy and examine how remote education has reconditioned interaction within craft classes in Finland.

Finnish craft education has been developed within Craft Science, which is a specific Nordic academic discipline (Kokko et al., 202O; Kokko, 2021). In Finland, the roots of craft science are on researching craft education and the teaching of it. The research presented in this article relies on this methodological and theoretical ground. We base our article on data gathered in two webinars on remote craft education that we, as craft teacher educators, arranged for Finnish craft teachers and student craft teachers in autumn 2020. The qualitative data analysis revealed aspects of remote craft education that can be utilised when developing the future of craft education. 


\section{Finnish craft education in the context of global pandem- ic education}

The imperative of education and learning not to stop under any circumstances (UNESCO, 2020) leads educators to find ways to guarantee its continuation and retain a sense of normality (Popa, 2020). As teachers are often highly committed to their work, they strove to cope with the pandemic situation by adopting new digital pedagogical practices both in Finland (FINEEC, 2020; Ilomäki \& Lakkala, 2020) and elsewhere (e.g. Garzón Artacho et al., 2020; Giovannella et al., 2020). However, there are concerns about the quality of remote education and the fact that school closures put students in various countries in unequal situations (d'Orville, 2020). Furthermore, remote education inevitably requires digital tools and internet access, which are not readily available to students in low-income countries (d'Orville, 2020). Furthermore, many students may lack the supporting circumstances for remote learning, such as a peaceful space at home and parental support (Arnove, 2020).

The equity of education that has been topical in global educational policies concerns possibilities of educational equity related to issues such as gender, sexual orientation, ethnicity, religion, the socio-economic background of the students, the disparity of the resources available in different countries, and questions of inclusion (Alcott et al., 2018; d'Orville, 2020). Pandemic education has raised new equity concerns. In addition to the above-mentioned disparity of learning facilities, the equity questions expand to the unequal opportunities to engage and participate in arts, and creative activities (Choi et al., 2020), as well as the amount of support students and teachers receive for working in a new situation (Kini-Singh, 2020).

The Finnish National Core Curriculum for Basic Education 2014 (FNBE, 2016, published in English in 2016) includes various so-called artistic and practical subjects, namely crafts, music, visual arts, physical education, and home economics. In the curriculum, craft is described as 'an exploratory, inventive, and experimental activity in which different visual, material, and technical solutions as well as production methods are used creatively' (FNBE, 2016, p. 772). Accordingly, working methods, learning environments, and materials of both technical work and textile work are implemented within the craft subject.

In elementary education (Grades 1-6, age 7-12), crafts are mainly taught by the generalist class teacher, whereas in lower secondary schools (Grades 7-9, age 13-16) crafts are taught by subject teachers with specialised competence and qualifications for teaching crafts. Since the subject was formerly divided into textile work and technical work, there are often different subject teachers for 
these two study fields. Although crafts is nowadays a common subject consisting of both technical work and textile work, only a small number of craft teachers are qualified in both subject areas. Therefore, cooperation between craft teachers is crucial to reach the targets of the curriculum (Kokko et al., 2020).

In adult education, crafts tend to be more content-specific than in basic education. In Finland, liberal adult education institutions include adult education centres, folk high schools, learning centres, sports training centres and summer universities. Liberal adult education is based on the principles of lifelong learning and education for active citizenship, providing craft education in the form of subject-specific courses, such as upholstery or metalwork (MinEdu, 2021). Vocational education defines crafts by fields of vocational education and training, developing specialised competence and the skills required in working life in branches like textiles and fashion or the wood industry (MinEdu, 2019). Crafts in higher education are manifested as specialised knowledge in the field of science or study programme they precede, such as craft teacher education or apparel design.

A recent report on the effects of the pandemic on the equity of education in Finland (FINEEC, 2020) revealed differences in the capacities of teachers and schools to arrange quality remote education. Schools differ in their approaches and capabilities to provide their students with adequate tools and materials for remote learning. The Finnish Education Evaluation Centre report (FINEEC, 2020) revealed that teachers in Finnish non-formal liberal adult education had experienced more difficulties in remote education than teachers in basic education. An essential factor related to this was the challenges that adult students of liberal education had in using Information and Communications Technology (ICT). Research has also revealed that teachers' workloads have increased due to remote education (FINEEC, 2020; Kini-Singh, 2020). According to Kini-Singh (2020), this relates especially to creative arts teachers, who have needed to adapt traditional art and design teaching techniques and invent new pedagogical solutions for teaching creative skills. However, in line with Wood (2021), we perceive craft as a paradigm that has powers and possibilities as a praxis of positive change due to its heterogeneity, pace and value placed on human-centred production.

\section{Method}

\section{The context and participants of the study}

Data were collected via two open webinars on remote craft education arranged by the present study's authors in autumn 2020. As professionals working in craft teacher education in Finland, we were also struggling with arranging 
quality remote education. Hence, we acknowledged the puzzling situation faced by the educators and wanted to provide a platform for exchanging ideas for the development of remote learning and teaching practices. Bearing this in mind, the first webinar focused on the experiences and good practices of remote craft pedagogy, while the second webinar focused on future visions of remote craft education. Both three-hour webinars included two expert presentations, discussions, and group work sessions. The webinars were organised via the Zoom video conferencing platform.

Because this is the first study on remote craft pedagogy, we wanted to collect data about it across various sectors and levels providing craft education. The participants included teachers from elementary and lower secondary school, vocational education, university-level teacher education, and liberal adult education and basic art education in crafts. In addition, student craft teachers participated in both webinars. Altogether, 257 participants (138 in Webinar 1, 119 in Webinar 2) took part in the webinars; most of them engaged in both webinars, but some only participated in Webinar 1 or Webinar 2. We aimed to collect data from the webinar groupwork sessions; however, not all participants engaged in the group work but left the webinar at that stage. Table 1 provides an overview of the webinar participants and group work organisation. In the first webinar, 75 group work participants were divided into 18 groups (3-5 persons per group) via the breakout room function in Zoom. According to their feedback, we enlarged the group size for the second webinar to enable more active interaction in the groups. Thus, 48 group work participants in Webinar 2 were divided into nine random groups, with 4-7 persons in each.

\section{Table 1}

Webinar participants and group work organisation

\begin{tabular}{lccccc}
\hline Webinars & $\begin{array}{c}\text { Webinar } \\
\text { participants }\end{array}$ & $\begin{array}{c}\text { Participants in } \\
\text { groupwork }\end{array}$ & $\begin{array}{c}\text { Number of } \\
\text { groupwork } \\
\text { documents }\end{array}$ & Group size & Group task \\
\hline Webinar 1 & 138 & 75 & 18 & $3-5$ persons & $\begin{array}{l}\text { Implementation } \\
\text { and impacts of } \\
\text { remote craft } \\
\text { pedagogy }\end{array}$ \\
\hline Webinar 2 & 119 & 48 & 9 & $4-7$ persons & $\begin{array}{l}\text { Future visions } \\
\text { of remote craft } \\
\text { pedagogy }\end{array}$ \\
\hline Total & 257 & 123 & 27 & & \\
\hline
\end{tabular}


Most of the group work participants (Webinar 1, 43\%; Webinar 2, 62\%) were subject teachers from basic education, with an educational background and teaching experience in textile crafts (Figure 1). Also, teachers from other sectors represented mainly textile crafts. The participating student craft teachers were undertaking combined crafts, expertise in both textile and technical work. As organisers of the webinars, our teaching and research context is within craft science and craft pedagogy in general; however, our background and experience derive mostly from the field of textile crafts. Although the webinars targeted all craft teachers, our expertise and networks based on textiles might have produced slightly more textile craft-oriented content and audience.

\section{Figure 1}

Webinar group work participants
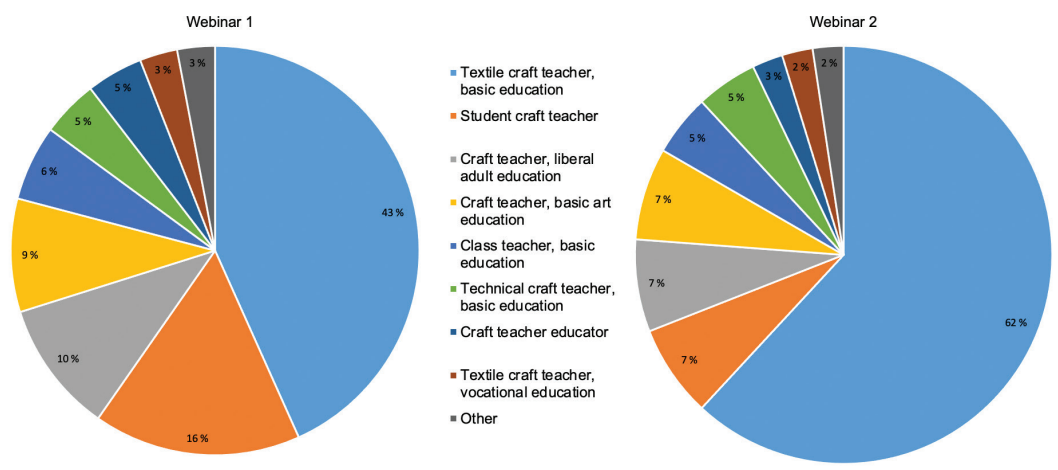

\section{Data and analysis}

The data consist of the material the participants produced in the group work sessions during the two webinars. In the first webinar groupwork task, participants were asked to discuss and write down how they had been implementing crafts during the pandemic, with guiding questions interested in 1) study assignments; 2) teaching methods; 3) digital platforms and tools; 4) craft materials, tools and equipment; and 5) support on interaction. In addition, each group was asked to propose an outline for a remote craft task based on the topics, themes, and phenomena that came up in the discussions. As an outcome, each group produced an online document on the implementation and impacts of remote craft pedagogy.

In the second webinar, the groups were provided with the classical thinking tool 'six thinking hats' (De Bono, 1985) as a framework for their task. 
The participants were asked to consider their visions of remote craft education by mentally wearing and switching 'hats' from six viewpoints, contemplating 1) the facts; 2) positives and probe for value and benefit; 3 ) risks, difficulties and problems; 4) feelings, hunches and intuition; 5) possibilities, alternatives, and new ideas; and 6) management of the thinking process (De Bono, 1985). As an outcome, each group produced an online document on the prospective views and visions of remote craft education. Altogether, the two webinar groupwork sessions produced 27 documents on the pedagogical practices and perceptions of remote craft education considered as the data for the study (Table 1).

The first stage of analysis involved pre-coding (Table 2) the material from the first webinar. In this stage, each group work document from the first webinar $(n=18)$ was coded inductively (Krippendorff, 2004; Kyngäs, 2020) into nine categories using Atlas.ti software (Friese, 2012).

\section{Table 2}

Pre-coding scheme, listed based on the appearance of expressions

\begin{tabular}{lc}
\hline Pre-code & $\begin{array}{c}\text { Consisting of } \\
\text { n expressions }\end{array}$ \\
Implementation of remote pedagogy & 91 \\
Remote learning phenomena or learning tasks & 90 \\
Remote learning platforms and digital tools & 73 \\
Confrontations, demands and limitations within remote craft pedagogy & 57 \\
Materials and resources for remote craft pedagogy & 51 \\
Social interplay and means of communication during remote education & 43 \\
Situational modification of pedagogy & 37 \\
Learning arrangements and methods & 31 \\
Advantages and benefits for remote craft education & 18
\end{tabular}

The categories were not exclusive, which means that data excerpts may have included details representing different categories. For instance, the expression 'I made teaching videos on YouTube that I linked to students in connection with assignments' (W1:G4) is associated with four pre-codes, consisting of implementation of remote pedagogy, remote learning platforms and digital tools, social interplay and means of communication during remote education, and learning arrangements and methods.

In the second stage of the analysis, the pre-codes were refined one by one, and the descriptive content of each pre-code was re-categorised based on the content of the expression. Some pre-coded categories appeared to be richer 
in content and more comprehensible in the description regarding the critical points of the data. At this stage, three core categories were formed: 1) challenges, 2) opportunities, and 3) ways of interaction. Each core category consisted of smaller subcategories and themes (Appendix 1). Content-wise, challenges and opportunities came up as contrary core categories, which divided the data into positive and negative attributes. In addition, the data consisted of rich and layered attributes regarding reciprocal learning activities, technology-enhanced communication, and means of giving and receiving feedback. These could not be categorised as either positive or negative effects of learning; instead, they revealed experiences and ideas of change relating to interaction amid remote education. The initial analysis guided the planning of the second group assignment. Consequently, we regard the smaller data set collected from the second webinar (i.e. nine groupwork documents) as complementary to the initial analysis, and the data were categorised accordingly.

Our own subjective experiences of teaching craft remotely might have affected the methodological decisions of the present study. On the one hand, our experiences helped us create a setting in which we could collect reliable and valid data. On the other, our ambition to develop remote and digital craft pedagogy might have provoked us to highlight the positive attributes in the analysis. While aiming for an academically sound empirical study, we also wanted to provide research-based evidence that remote craft pedagogy can and needs to be developed. However, we aimed to ensure the reliability of the study through transparency of the analysis and interpretation. When presenting the results in the following, the data excerpts are identified by codes based on the order of the webinars (W1 $=$ Webinar $1, \mathrm{~W}_{2}=$ Webinar 2$)$ and documents produced during the group work ( $\mathrm{G} n=$ group, number of the group).

\section{Results}

\section{Challenges of remote craft pedagogy}

\section{Differentiation in and across craft subjects}

The educators across the craft sector described complex and diverse concerns regarding the extensive digital transformation required to adapt craft pedagogy to an online learning environment. One of the main concerns for the teachers in basic education was that the skills and capabilities of young students were not sufficient for online learning where the teacher's direct guidance was not readily available. On this note, craft teaching for younger students was regarded as challenging because of the students' low level of basic craft skills and 
lack of technological competences. Difficulties in remote craft pedagogy were also reported in relation to students' linguistic challenges. Coincident issues were also addressed in other levels of education, for instance, in relation to the insufficient technological competences of older adults undertaking crafts in liberal adult education.

In addition, challenges were reported in terms of the unequal distribution of material resources across schools, classes, and regions. In mid-March, only a week before the school closure, the Finnish National Agency for Education recommended that school staff and teachers were advised to counsel students to take home materials and equipment they might need for remote studies and for independent work (FNAE, 2020). Many schools provided students with small material packages containing basic materials for crafting, such as needles, yarns, cloth, wood, and nails. Some students could take their unfinished craft projects with them and continue their craft learning processes at home. Some teachers reported that they managed to deliver material packages for some students, classes, or learning groups, but not for all. Sometimes teachers experienced difficulties delivering the materials since students were unable or unwilling to fetch them from school. There were also differences in the material resources of students' homes across the country. Teachers reported that craft materials and tools were readily available in homes in rural areas. In contrast, teachers in urban areas assumed that schools were the only source for specific craft materials, as only very basic equipment or materials (e.g. scissors and cardboard) were found in students' homes.

The role of crafts in the context of other school subjects in basic education was discussed. Several teachers reported that subjects other than crafts were given priority in teaching, and some schools did not teach crafts remotely. We see this as reflecting the greater value given to the so-called academic school subjects, such as mathematics, the mother tongue, and sciences (Nussbaum, 2010). The teachers had noticed that craft learning tasks were regarded as somewhat voluntary and, therefore, they were undertaken only if the families could support remote learning. These accounts are in line with a study of parental support during remote learning, concluding that many children, regardless of their age and capabilities, who would have normally pursued learning rather independently, were in urgent need of extra support during the Covid-19 outbreak (Koskela et al., 2020). The teachers in this study described that craft learning tasks required particular attention and expertise from the parents because the material practices of the subject and craft were, at times, regarded as 'an 'extra' for both schools and homes, and too burdensome when parents had to participate' (W1:G8), as argued by a teacher in basic education. Without a 
doubt, it would be unrealistic to expect parents to be capable of expert guidance in the remote education of crafts (Freedman \& Escaño, 2020). Some teachers reported that some parents, as well as the school authorities, were not appreciating the pedagogical value of the material and experience-based practices of craft education. Learning based on creative activities, such as craft projects, is more challenging to perceive and evaluate than learning taking place through structured textbook activities. In the challenging situation caused by the pandemic, this might have negatively affected the value given to craft education. All in all, the data analysis revealed that resources for remote craft education varied greatly, which ultimately created inequalities between students, classes, schools, and areas, resulting in a situation where some students were provided better possibilities to cope with pandemic craft pedagogy than others.

\section{Changes in teaching practices during remote education}

Practices for implementing and organising craft education during the Covid-19 outbreak varied at different levels of education. In our study, the class teachers in elementary education reported that they usually met the pupils online every day. These meetings were arranged with the whole class being present or as individual student guidance sessions. In lower secondary schools, remote education was most often arranged in different subjects taught by respective subject teachers at a scheduled time. In vocational education, university teaching, and liberal arts education, the course meetings were also arranged at a scheduled time.

According to the teachers' descriptions, craft lessons were mainly constructed similarly throughout the remote education period at different levels of education. The learning tasks were most often given at the beginning of a session, with the teacher's instructions comprising a weekly assignment and an overview of the materials and tools needed for the learning task. After the general information and learning assignments, the students could stay online or start working on the assignments on their own. Many educators across the craft sector reported having arranged lessons with an open meet channel during the scheduled session so that the students could ask for help if needed.

Digital competence is regarded as one of the main challenges the educational community faces (e.g. Garzón Artacho et al., 2020), and this became evident in our study. The planning of remote craft pedagogy was considered more time-consuming than normal classroom teaching (see, also, Iivari et al., 2020). Educators reported having felt inadequacy and experienced remote craft pedagogy as 'scrambling at a fast pace' (W1:G6), which, they assumed, could 'compromise the quality of teaching, among other things, due to a lack of materials and tools' (W1:G18). A general opinion among the educators, frequently 
repeated in the data, was that crafts were not suitable for remote education in an optimal way, since 'crafts is a know-how subject where learning requires contact and hands-on working' (W2:G1). The educators also reported that learning and teaching new skills in online environments was impractical and laborious. They felt that when hands-on teaching was absent, there were less familiar pedagogical tools for managing the material practices of the subject. Many teachers put effort into writing feedback to the students, which required time allocation and effort. They also argued that 'habituated video conferencing practices were monotonous and the enthusiasm for students' task returns was poor' (W1:G5). We see this as reflecting the fact that the emergency remote pedagogy did not allow the teachers to prepare their pedagogy thoroughly. In their study on online teaching, Ilomäki and Lakkala (2020, p. 75) point out that this kind of teaching 'requires specific knowledge of pedagogy, content, and technology, compared to situations in which the teacher meets students face-to-face'.

The analysis indicates that the teachers had created individual coping strategies. In most cases, learning tasks were constructed as weekly or bi-weekly tasks, especially for older students. Younger students were often given their assignments daily. However, many responses insisted that remote craft education was experienced as scattered and disorderly, lacking a sense of purposefulness and long-term task orientation, which teachers are normally accustomed to when aiming to reach the targets of the crafts curriculum of basic education (FNBE, 2016, p. 772). Moreover, the fact that the duration of the pandemic was not known complicated efficient planning, as was argued by a group of teachers in their reflection on the beneficial outcomes of remote craft education: 'Remote education could be consistent and worthwhile if there were a proper plan, and the shift to the remote education would not be so sudden' (W2:G3).

\section{Constraints imposed by tasks and materials}

The educators reported having responded to the new situation by adapting and adjusting the curriculum-based learning tasks, dividing tasks into smaller assignments, and developing variations, which required them to change from holistic problem-based learning tasks to accomplishment-based, and sometimes mostly theoretical, tasks. It was reported that the role of handson making diminished, and tasks focusing on designing and planning, as well as assignments concentrating on material studies, increased. When trying to reach the curriculum targets, the teachers often used ICT to continue their normal pedagogy, reflecting that the teachers did not have time to prepare for the abrupt situation. However, it is essential to develop pedagogy suitable for utilising digital technology for teaching to be efficient. 
In our study, the teachers from basic education continued to follow the general curriculum goals of craft education. However, the response to the goals was reoriented, as the importance of online learning was emphasised, and the contents of the tasks were reassessed. To avoid misunderstandings, educators across the craft field reported having acknowledged students' need for clear instructions. More written assignments were given at the university level, and the students were expected to have access to the materials and tools for producing crafted coursework. In liberal arts education, remote craft classes were mainly based on students' independent work. Some craftwork assignments could be completed at home, but some techniques, such as weaving or pottery, were 'difficult to implement without proper tools and materials' ( $\left.\mathrm{W}_{1}: \mathrm{G}_{3}\right)$, as was argued by the liberal adult education teachers.

If material packages were not delivered, resources for crafting became increasingly limited. In particular, teachers working with younger students were often concerned about the conditions for learning. Safety is an important prerequisite for all education, and the teaching of crafts requires special safety considerations (Inki et al., 2011). The teachers reported having worries about the safety of the students, as 'retrieving [natural] materials [outdoors] may not be safe' (W1:G3), and concerns about craft assignments, which required the students to operate with scissors, knives, or other handicraft tools. Nevertheless, some teachers commented that online craft education was taught 'just as normal' (W1:G7), emphasising that the phases within the remote craft learning process remain comparable to those of the normal classroom pedagogy. However, educators across the craft field felt that learning in online environments required more concentration from both students and teachers than in face-to-face sessions.

\section{Opportunities for remote craft pedagogy}

\section{Digitalisation broadening understanding of the craft subject}

Although digital tools and technologies have been used extensively in Finnish schools (Mannila, 2018; Niemi et al., 2013), classroom teaching and learning methods have not changed remarkably (Hakkarainen et al., 2015). According to a recent large-scale investigation in Finnish schools, the creative use of digital technologies, such as digital designing or fabrication, or programming, has remained scarce (Korhonen et al., 2020; see also Laurell et al., 2021). Although some subject-specific digital tools, such as $3 \mathrm{D}$ printers and laser cutters, have been utilised in craft classrooms and maker spaces in recent years (Bosco et al., 2019), digitalisation was not profoundly integrated into Finnish craft learning before the Covid-19 pandemic. 
During the Covid-19 outbreak, the participants in this study used an extensive range of digital platforms and applications to sustain remote craft education: live classes were held via video conferencing and VoIP tools. Instructions were delivered through messaging on WhatsApp and remote communication web services, such as Wilma and Helmi. The outcomes of the learning processes were mediated via digital distribution platforms, online portfolios, and learning assessment tools. In addition, interactive platforms were used to support students' peer interaction. In adult education, meetings are also extended to live sessions.

Educators used different tools and platforms depending on the situation; their own digital skills, competences, and readiness to use technology; and the resources provided by the institution. The schools' guidelines were not unified either; for instance, some teachers were not allowed to use Zoom or Google accounts due to security issues. However, educators generally felt that they eventually succeeded in coping with the digital interface, adopting new tools and technologies to craft pedagogy, and choosing best practices according to the goals of education. This is reflected, for instance, in a response of a lower secondary school teacher, in the request to give orderly instructions to students in their online craft learning tasks: 'Practices [for instance in returning craft assignments] should be clear and more or less the same every time, so the students won't get mixed up with too many instructions and platforms, where to document what as their response to a learning task' (W1:G13).

The Finnish craft curriculum emphasises the importance of good planning and process documentation (FNBE, 2016, p. 774). Moreover, with the transition to an online environment, the documentation of craft processes has gained more attention. Overall, educators across the field considered augmenting the documentation of craft processes with photos and videos to be beneficial. When thinking of future remote craft education, the educators even envisioned that project documentation could be arranged in craft subject in video format, for example, in a type of ' 5 -minute crafts video' illustrating phases of crafting. All in all, process documentation and reflections appeared to be decisive in mediating knowledge between the students and the teachers during remote education and provided valuable support for learning and teaching crafts.

\section{Empowerment in action: student-centred craft learning}

In terms of the learning tasks given by the teachers, crafting was widely linked to students' own lives, home environments, and personal interests. Some craft learning tasks were inspired by the phenomena derived from leisure activities and popular culture of this age group and students' homes and neighbourhoods. 
These examples given by the craft teachers refer to meeting the pedagogical objectives of craft education (Pöllänen, 2019) when the students considered a range of design constraints in their crafting and eventually evaluated the outcomes of the process. In this way, craft learning during remote education appeared to promote an understanding of real-world problem solving and enhanced the integration of skills in various contexts from the students' perspectives.

Some liberal adult education teachers provided students with packages of craft course materials. Interestingly, they argued that the demand for materials in liberal adult education courses increased compared to the pre-pandemic situation. When almost all of society came to a standstill, crafting thrived as a hobby, positively contributing to life through times of stress, as 'there was more time for crafting' ( $\mathrm{W}_{1}: \mathrm{G}_{7}$ ). Thus, according to the educators, pandemic craft education within adult education seemed to provide much-needed empowerment for people stressed by social distancing.

The teachers recognised that the students could focus on studying at their own pace in their own private spaces at home without the interruptions and distractions that usually occur in classrooms. Furthermore, these examples revealed that remote craft pedagogy allowed the students to personalise their learning with available resources, which enabled malleable craft learning tasks, where the evaluation of the process was based on the learners' interpretation.

\section{The rise of sustainability thinking through crafting at home}

One of the most decisive recent changes within Finnish craft education concerns the aim to create diverse, multi-material, and in-depth learning tasks for the students (Kokko et al., 2020; Porko-Hudd et al., 2018; Pöllänen, 2019). One of the strengths of remote craft pedagogy revealed in the current study was the versatility of learning perspectives. Many educators had implemented craft learning tasks within broad areas, such as recycling, material knowledge, and global education. In addition, craft learning tasks often addressed real-life challenges, such as fixing skateboards or mending clothes. In general, the learning tasks during remote education comprised assignments on complex local and global phenomena. Thus, the students were encouraged to learn artisanship from a sustainability perspective, as they were not buying new materials but utilising existing ones, engaging in 'every day, homely creativity with which to look at things differently' (W1:G10). Many projects were based on the 'making it from scratch' mentality' ( $\left.\mathrm{W}_{1}: \mathrm{G}_{4}\right)$, utilising materials readily available in homes, grocery stores, and nature.

In basic education, learning was often grounded on themes including 'coziness, functionality, maintenance, and recycling' (W1:G10), and sustained 
with craft assignments concentrating on upcycling, décor, and maintenance at home, or tasks focusing on students' wardrobe or style, such as wardrobe inventories or arrangement tasks. With the help of ready-made e-learning materials - most commonly retrieved from the craft learning database PUNOMO (https://punomo.fi) and the websites of craft teacher organisations - teachers constructed various learning tasks for crafts. These tasks included activities such as face mask sewing, insect hotel building, bicycle maintenance and cleaning the water trap from the sewer. There were also assignments for researching crafts by searching for information, such as learning about craft traditions and discussing them with grandparents.

At times, craft learning relied on parental support and the housework done at home. Sometimes the learning tasks were integrated with other school subjects. As described by a lower secondary school craft teacher, 'wooden boards for making flamed salmon [which were accomplished during the Covid-19 remote teaching] were set for trial, and I got photos of real uses of the boards in May. At that point, craft learning was integrated with home economics, and I asked about tasting and possible side dishes for a salmon meal. Parents were also nicely involved in this additional task' (W1:G18). The teacher gave this as an example of a successful remote pedagogy assignment, which integrated crafts with other school subjects and contributed the perception of the meanings of crafts in everyday life so that the parents could be involved in the students' learning process. All in all, collaboration with parents in regard to materials and conditions for craft learning was considered a meaningful practice often neglected in craft education.

\section{Interaction in remote craft pedagogy}

\section{Teacher leadership in communication and interaction}

Although craft learning is essentially student-centred, our analysis suggests that remote craft education tends to be teacher-led. The teachers reported that written assignments and commenting on them took on an emphasis over hands-on making. Although teachers gave more written feedback and tailored their teaching to support the students, the interaction was often teacher-led.

The unexpected situation caused by the pandemic enhanced collaboration between craft teachers. Responses indicate that there was more cooperation between the technical and textile craft teachers in many basic education schools during the Covid-19 outbreak compared to the pre-pandemic time. Sometimes the content of craft lessons was divided week-by-week between textile work and technical work taught by respective teachers: 'Every other week 
students undertook tasks in technical work, such as bike maintenance, and every alternate week in textile work, such as ironing' (W1:G10). The craft teachers reported having intensified collaboration to reach the common targets and to cope with the difficult situation, as reflected in the following:

'There is a need to develop new ideas for craft pedagogy and look afresh at education organised from a distance. It is not just thinking about how I would implement contact teaching remotely. Forms of remote education should be developed collaboratively in a coordinated way so that there is peer support for developing new methods for changing education' (W2:G5).

The educators had developed new routines to overcome the challenges related to remote craft teaching. Some of them even insisted on including collaborative lessons if the remote education period continued. In addition, teachers wished for deeper collaboration between craft teachers across schools, stating that

'sharing materials and ideas should be freer and more easily accessible' (W2:G2).

Most participants in this study reported that interaction was hard to maintain online. Particularly at the beginning of the outbreak, the situation was regarded as difficult and stressful. There were experiences of setting up new routines for overcoming the challenges related to remote craft teaching. Educators were readily developing their methods for remote teaching during Covid-19, dividing large study groups into smaller groups, and setting up oneto-one supervision with students. The overall goal was to have all students present and keep their workload reasonable.

\section{More personalised feedback from the teacher - less peer interaction among students}

It has been argued that remote education has increased awareness of the technology affordances for learning, including better opportunities for giving feedback to students (Giovannella et al., 2020). Indeed, teachers in this study also reported students receiving more personal feedback during remote education than before, both in writing and via video conferencing tools or oneto-one messaging. In essence, teachers spoke about personal student guidance and good conversations over the phone or via Meet 'when there wasn't the same rush as there often is during the hours working with a large group' (W1:G14), and that students enjoyed receiving specific, personalised feedback. 
Interestingly, educators recognised that contact with some students was even better during remote education than before. When the students collaborated online, for instance, retrieving information on the internet and posting their findings on a shared community platform, all students could have their comments and ideas visible and equally delivered on the screen.

Supporting students' peer interaction in remote pedagogy is a frequently raised challenge revealed in the research (Ilomäki \& Lakkala, 2020). In this study, the interaction between students alternated from vivid conversations to complete silence. Teachers acknowledged that when the interaction among the students was text-based, it was not easy to generate conversation. In group situations, the conversation was often stiff and tense. In essence, the educators felt that they lacked the tools to support and sustain interaction. Therefore, attempts were made to encourage interaction and peer feedback via video meetings, chats, and questionnaires.

'There were many kinds of interactions in varying circumstances. In upper secondary school, the initial fatigue came to the students after about a month. Some took advantage of distance learning as an opportunity to laze, and they weren't very active after a month. Much depended on the student' (W1:G14).

Challenges in supporting interaction also concerned adult education. In vocational education, some textual assignments were based on peer feedback and thus required student interaction. At the university level, the teachers reported experiences of speaking to a blank screen and their success in creating interaction during a feedback session when the students presented their work. All in all, teachers experienced difficulties in getting all students to be online simultaneously, and students often remained distant and quiet during the online group meetings.

Generally, it was experienced that the younger the students were, the more interaction there was during online teaching. However, the interaction was also vibrant in liberal adult education, where learners dwell in a human-centred pedagogical frame. Acknowledging that interaction flourished in situations where the frame for teaching and learning was open-ended and adaptive paves the way for developing meaningful pedagogical practices for remote craft education. 


\section{Discussion}

The prevailing experience of the study participants was that arranging remote craft education had caused an enormous workload for the teachers. In fact, according to Kin-Singh (2020), pandemic pedagogy has increased the workload of creative arts teachers, in particular, who have worked hard to invent new pedagogical solutions to teach these subjects remotely. Therefore, in their attempt to reach the targets of the curriculum, the educators of this study needed to rethink all aspects of their pedagogy, including the availability of craft materials, tools, and equipment and reconsidering the space in which the students could practice their hands-on activities. In reflection, they faced new challenges in embracing digital tools to support their students online. After all, the educators shared the idea of crafting as a material practice, which requires face-to-face contact and social interaction between teachers and students.

However, the teachers also reported having developed creative pedagogical solutions that could be utilised later, even after the pandemic crisis. They recognised digital technology's opportunities for more individual student guidance and feedback than the usual classroom environment. In addition, learning assignments were often formulated to cover wider societal and cultural themes than previously in ordinary teaching. Often, the assignments of remote craft education touched the students' everyday lives, involving their homes in craft studies.

Fullan (2020) points out that the education system was, in fact, in need of changes after a long-stagnant period that has allowed education to continue without major changes. He sees the crisis as an opportunity for positive change, although he also sees the risks of the proliferation of technology without good pedagogy being developed in parallel with it. According to Hughes (2020), pandemic pedagogy has forced educators to concentrate on the very core of teaching in their subject area. As Robinson (2020, p. 7) states, we need to think carefully 'what kind of normal do we want to go back to?' as this is an exceptional moment to redirect our course. Obviously, there is a need to educate teachers to find digital pedagogical solutions for their remote pedagogy. As Aguilera and Nightengale-Lee (2020) recognised, the best results are not reached by replicating the existing social practices of classroom pedagogy but by establishing new, more flexible practices for undertaking teaching and learning for the purposes of remote education. In line with these studies, the findings of our study indicate that the pandemic caused craft teachers to create new pedagogical solutions and approaches, such as establishing new digital skills and feedback practices via online platforms, developing a wide range of learning topics centred around sustainability and household, and delivering virtual workshops and classes to sustain collaboration among teachers, 
that might be worth keeping up in the post-pandemic era. These new practices of utilising digital possibilities will have a long-term impact on the implementation of craft education.

The analysis revealed the disparities among the range of schools, teachers, students, and homes to attend and implement remote craft pedagogy. This puts them in an unequal situation, which is a serious concern in remote pedagogy both in Finland (FINEEC, 2020) and globally (d'Orville, 2020). Schools have different opportunities to provide their students with adequate materials and tools for remote craft studies. Teachers' and students' abilities to use digital tools differ, as does their access to them. In addition, craft activities put certain conditions on space that each home cannot always be granted (see Arnove, 2020). The teachers in this study were especially concerned about the students with the weakest craft knowledge and poorest technological capabilities, as they could not be supported directly by the teacher.

This study emphasised the earlier findings of the inequities among school subjects, placing the theoretical subjects above artistic and practical subjects in the hierarchy (Nussbaum, 2010). The teachers in this study reported that priority was given to the theoretical subjects, as their teaching was also ensured in emergency remote education. Crafts were often the last subject to be considered, and in some schools, crafts were not taught during the lockdown. Unfortunately, these findings reflect on 'the silent crisis' of the downsizing of arts and humanities that runs through society and the education system, in which the learning of skills is often disregarded in contrast to more profitable subjects that are seen to have a greater contribution to the nation's rush to profitability in the global market (Nussbaum, 2010). In light of research, these findings are alarming, since they have repeatedly underlined the need to cultivate creative competencies of all citizens to meeting the complex global challenges we face today and in the future (Kini-Singh, 2020). Artistic and practical subjects play a key role in developing these competences from the early stages of education since they, through their very premise, focus on creative ways of thinking and acting. Their full potential cannot be justified in terms of what they can do for more theoretical subjects, such as mathematics or science, but rather in terms of what they directly deliver (Hetland et al., 2013). Creative approaches to education have a learning heuristic of their own, where experience-based practices are used for problem-solving, learning, investigating, and discovery. The practices include, for example, mentally envisioning what cannot be directly observed or imagining possible next steps, expressing ideas or personal meanings, exploring playfully without a pre-structured plan, and embracing mistakes as learning opportunities (Daugherty, 2013). Without these practices, many novel and innovative approaches to learning might never be found. 


\section{Conclusions}

Since the webinars in which the data were gathered were voluntary, we can assume that the data consisted of the views of educators who were interested in developing remote pedagogy and were already keen on developing their digital competences. This may be reflected in the findings regarding the lack of criticism of remote learning technologies. Indeed, as the discussion of teachers' own technological skills and possible shortcomings was left behind in the context of craft teaching, greater value was put on the characteristics, challenges, and opportunities that can constrain, reverse, and mitigate remote learning and teaching practices of the subject. Thus, the findings manage to go beyond user-related technological issues, which are often easy to get stuck in, and, hopefully, underpin the productive policy and practical application of remote craft pedagogy in the future. Consequently, the findings may provide a more positive view of remote craft education in Finland than the situation found in the country in general. Therefore, the findings of this study are not meant to be generalised; rather, the purpose is to reveal the range of aspects related to remote craft pedagogy.

Although the present study's findings revealed both challenges and opportunities in remote craft pedagogy, the general perspective tended more to the negative side. It was challenging for the teachers to meet all the requirements of the craft curriculum via remote education. Furthermore, many important aspects of craft education, such as learning through creative and collaborative material practices, were diminished or even vanished in remote teaching. We conclude that craft education does not adapt well to existing remote education solutions; however, some aspects can be implemented through remote means. For example, providing more individual feedback or including more students' interests in the learning tasks were easier to realise remotely.

As most informants in this study were craft teachers of basic education, their views are emphasised in the findings. Although we touched on the experiences from other educational levels, more research from remote craft pedagogy at different educational institutions is needed. Here, we concentrated on the teachers' experiences and views; research is also needed on the students' experiences and learning outcomes of remote craft education as well as guardians' experiences of supporting children's learning of craft at home. In addition, developing more suitable remote education solutions for craft and other artistic and practical subjects would provide interesting avenues for future research. 


\section{References}

Alcott, B., Rose, P., Sabates, R., \& Torres, R. (2018). Handbook on measuring equity in education. UNESCO Institute for Statistics. http://uis.unesco.org/sites/default/files/documents/handbookmeasuring-equity-education-2018-en.pdf Arnove, R. F. (2020). Imagining what education can be post-COVID-19. Prospects, 49(1-2), 43-46. https://doi.org/10.1007/s11125-020-09474-1 Aguilera, E., \& Nightengale-Lee, B. (2020). Emergency remote teaching across urban and rural contexts: Perspectives on educational equity. Information and Learning Sciences, 121(5/6), 471-478. Bosco, A., Santiveri, N., \& Tesconi, S. (2019). Digital making in educational projects. Center for Educational Policy Studies Journal, 9(3), 51-73. https://www.cepsj.si/index.php/cepsj/article/ view/629/367

Choi, M., Tessler, H., \& Kao, G. (2020). Arts and crafts as an educational strategy and coping mechanism for Republic of Korea and United States parents during the COVID-19 pandemic. International Review of Education, 66(5), 715-735.

Coleman, K., \& MacDonald, A. (2020). Art education during the COVID-19 lockdown. https://www. teachermagazine.com.au/articles/art-education-during-the-covid-19-lockdown?lang=en Daugherty, M. K. (2013). The prospect of an "A" in STEM education. Journal of STEM Education: Innovations and Research, 14(2), 10-15.

De Bono, E. (1985). Six thinking hats. MICA Management Resources.

d'Orville, H. (2020). COVID-19 causes unprecedented educational disruption: Is there a road towards a new normal? Prospects, 49(1-2), 11-15. https://doi.org/10.1007/s11125-020-09475-O FINEEC [Finnish Education Evaluation Centre]. (2020). Poikkeuksellisten opetusjärjestelyjen vaikutukset tasa-arvon ja yhdenvertaisuuden toteutumiseen Osa I: Kansallisen arvioinnin taustaraportti, synteesi ja tilannearvio valmiiden aineistojen pohjalta [The impacts of exceptional teaching arrangements on equity. Part I: The background report of national assessment, synthesis and estimation based on existing data]. https://karvi.fi/app/uploads/2020/05/Poikkeuksellistenopetusj\%C3\%A4rjestelyjen-vaikutukset-osa-I-Karvi-7.5.2020-1.pdf FNAE [Finnish National Agency for Education]. (2020, March 13). Education services and the coronavirus. https://www.oph.fi/en/news/2020/education-services-and-coronavirus FNBE [Finnish National Board of Education]. (2016). National core curriculum for basic education 2014. Publications 2016: 5. Finnish National Board for Education.

Freedman, K., \& Escaño, C. (2020). Reflections from education and the arts in the COVID-19 era. Reflections IX, X. Communiars. Revista de Imagen, Artes y Educación Crítica y Social, 4, 25-28. https://idus.us.es/handle/11441/100833

Friese, S. (2012). Qualitative data analysis with ATLAS.ti. Sage.

Fullan, M. (2020). Learning and the pandemic: What's next? Prospects, 49(1-2), 25-28. https://doi. org/10.1007/s11125-020-09502-0

Garzón Artacho, E., Martínez, T. S, Martín, J. L., Marín, J., \& Gómez García, G. (2020). Teacher 
training and lifelong learning: The importance of digital competence in the encouragement of teaching innovation. Sustainability, 12(7), 2852. https://doi.org/10.339o/su12072852 Giovannella, C., Passarelli, M., \& Persico, D. (2020). The effects of the Covid-19 Pandemic on Italian learning ecosystems: The school teachers' perspective at the steady state. Interaction Design and Architucture(s), 45, 264-286. http://www.mifav.uniroma2.it/inevent/events/idea2010/doc/45_12.pdf Hakkarainen, K., Hietajärvi, L., Alho, K., Lonka, K., \& Salmela-Aro, K. (2015). Socio-digital revolution: Digital natives vs. digital immigrants. In J. D. Wright (Ed.), International encyclopedia of the social and behavioral sciences ( $\mathrm{Vol} 22$, 2nd ed., pp. 918-923). Elsevier.

Hetland, L., Winner, E., Veenema, S., \& Sheridan, K. M. (2013). Studio thinking 2: The real benefits of visual arts education (2nd ed.). Teachers College Press.

Hodges, C., Moore, S., Lockee, B., Trust, T., \& Bond, A. (2020). The difference between emergency remote teaching and online learning. Educause Review. https://er.educause.edu/articles/2020/3/thedifference-between-emergency-remote-teaching-and-online-learning Hughes, C. (2020). COVID-19 and the opportunity to design a more mindful approach to learning. Prospects, 49(1-2), 69-72. https://doi.org/10.1007/s11125-020-09492-Z Ilomäki, L., \& Lakkala, M. (2020). Finnish upper secondary school students' experiences with online courses. Education in the North, 27(2), 73-91.

Inki, J., Lindfors, E., Sohlo, J., Aadeli, S., \& Bläuer, H. (2011). Käsityön työturvallisuusopas Perusopetuksen teknisen työn ja tekstiilityön opetukseen [Occupational safety guide for crafts-For teaching technical work and textile work in basic education]. Opetushallitus.

Iivari, N., Sharma, S., \& Ventä-Olkkonen, L. (2020). Digital transformation of everyday life: How the COVID-19 pandemic transformed the basic education of the young generation and why information management research should care? International Journal of Information Management, 55, 102-183. Kini-Singh, A. (2020). Art education in the time of a pandemic. http://www.unboundjournal.in/wpcontent/uploads/2020/o8/Amita_Kini-Singh_03_Critiques.pdf Krippendorff, K. (2004). Content analysis: An introduction to its methodology (2nd ed.). Sage. Kokko, S. (2021). Approaches to craft studies at higher education. FormAkademisk Forskningstidsskrift for Design Og Designdidaktikk. https://doi.org/10.7577/formakademisk.4197 Kokko, S., Almevik, G., Høgseth, H., \& Seitamaa-Hakkarainen, P. (2020). Mapping the methodologies of the Craft Sciences in Finland, Sweden and Norway. Craft Research, 11(2), 177-209. https://doi.org/10.1386/crre_0oo25_1 Kokko, S., Kouhia, A., \& Kangas, K. (2020). Finnish craft education in turbulence. Techne serien Forskning i Slöjdpedagogik och Slöjdvetenskap, 27(1), 1-19. https://journals.oslomet.no/index.php/ techneA/article/view/3562

Koskela, T., Pihlainen, K., Piispa-Hakala, S., Vornanen, R., \& Hämäläinen, J. (2020). Parents' views on family resiliency in sustainable remote schooling during the COVID-19 outbreak in Finland. Sustainability, 12(21), 8844. https://doi.org/10.339o/su12218844 Korhonen, T., Tiippana, N. M., Laakso, N. L., Meriläinen, M., \& Hakkarainen, K. (2020). Growing mind: Socio-digital participation in and out of the school context. Students' experiences 2019. University 
of Helsinki, Department of Education. https://doi.org/10.31885/9789515150189

Kyngäs H. (2020). Inductive content analysis. In H. Kyngäs, K. Mikkonen, \& M. Kääriäinen (Eds.), The application of content analysis in nursing science research (pp.13-21). Springer. https://doi. org/10.1007/978-3-030-30199-6_2

Laurell, J., Seitamaa, A., Sormunen, K., Seitamaa-Hakkarainen, P., Korhonen, T., \& Hakkarainen, K. (2021). A socio-cultural approach to growth-mindset pedagogy: Maker-pedagogy as a tool for developing a next-generation growth mindset. In E. Kuusisto, M. Ubani, P. Nokelainen, \& A. Toom (Eds.), Good teachers for tomorrow's schools - Purpose, values, and talents in education (pp. 296-312). Brill Sense.

Mannila, L. (2018). Digitally competent schools: Teacher expectations when introducing digital competence in Finnish basic education. Seminar.net. International Journal of Media, Technology and Lifelong Learning, 14(2), 201-215. https://journals.oslomet.no/index.php/seminar/article/ view/2980/2882

Milman, N. (2020). This is emergency remote teaching, not just online teaching. Education Week. https://www.edweek.org/ew/articles/2020/03/30/this-is-Emergency-remote-teaching-not-just.html MinEdu [Ministry of Education and Culture]. (2019). Finnish VET in a nutshell. Education in Finland. Ministry of Education and Culture. https://minedu.fi/documents/1410845/4150027/ Finnish+VET+in+a+Nutshell.pdf/9d43da93-7b69-d4b5-f939-93a541ae998o/

Finnish+VET+in+a+Nutshell.pdf

MinEdu [Ministry of Education and Culture]. (2021). Liberal adult education. https://minedu.fi/en/ liberal-adult-education

Niemi, H. M., \& Kousa, P. (2020). A case study of students' and teachers' perceptions in a Finnish high school during the COVID pandemic. International Journal of Technology in Education and Science (IJTES), 4(4), 352-369.

Niemi, H., Kynäslahti, H., \& Vahtivuori-Hänninen, S. (2013). Towards ICT in everyday life in Finnish schools: Seeking conditions for good practices. Learning, Media and Technology, 38(1), 57-71.

Nussbaum, M. C. (2010). Not for profit: Why democracy needs the humanities (Vol. 2). Princeton University Press.

Popa, S. (2020). Reflections on COVID-19 and the future of education and learning. Prospects, 49(1-2), 1-6. https://doi.org/10.1007/s11125-020-09511-Z

Porko-Hudd M., Pöllänen S., \& Lindfors E. (2018). Common and holistic crafts education in Finland. Techne Series: Research in Sloyd Education and Craft Science, 25(3), 26-38.

Pöllänen, S. (2019). Perspectives on multi-material craft in basic education. International Journal of Art and Design Education, 39(1), 255-270.

Robinson, S. K. (2020). A global reset of education. Prospects, 49(1-2), 7-9. https://doi.org/10.1007/ S11125-020-09493-y

UNESCO. (2020). \#LearningNeverStops. COVID-19 education response. UNESCO. https://en.unesco. org/covid19/educationresponse/globalcoalition.

Wood, D. (2021). Introduction: Re-crafting an unsettled world. In D. Wood (ed.), Craft is Political 
(pp. 1-17). Bloomsbury Publishing.

Øgaard, A. (2018). Conventional classroom teaching through ICT and distance teaching. Nordic Journal of Digital Literacy, 13(1), 9-23.

\section{Biographical note}

Anna Kounia, PhD, is an adjuct professor (docent) in craft science. She currently works as a university lecturer in Craft Teacher Education programme at the University of Helsinki, teaching across courses on yarn crafts, craft pedagogy, and crafting as material culture. Her research is driven by an interest in lived experiences at the intersection of crafting and materiality, building on making with methods of autoethnography and feminism. Her research focuses on textiles and dress, new materialism, community heritage, digital materiality, and the meanings of hobby crafts, especially emerging in social media and popular culture.

KAIJU KAngAs, PhD, is an assistant professor of technology education at the Faculty of Educational Sciences, University of Helsinki, Finland. Her research focuses on craft, design, and technology education from pre-primary to higher education, and she also develops pre-service and in-service teacher education in the field. Her main research interest is in the design and implementation of maker-centered learning in the classroom as well as in the related socio-material learning and teaching practices.

Sirpa Кокко, PhD, is an associate professor of craft science and craft pedagogy at the Faculty of Educational Sciences, University of Helsinki, where she is also the director of the study programme of craft science and craft teacher education. Her research concern arts and crafts in the culture and society and their role in education both in Finland and in international contexts, including topics of gender, cultural heritage, craft pedagogy, interdisciplinary education and sustainability. She has extensive experience in craft research and craft teaching in Finland and other countries. Dr Kokko is active in research collaboration in a range of both national and international projects. 